Article

\title{
Synchronous Growth Releases in Peatland Pine Chronologies as an Indicator for Regional Climate Dynamics-A Multi-Site Study Including Estonia, Belarus and Sweden
}

\author{
Aleksei Potapov ${ }^{1, *}$, Sandra Toomik ${ }^{2}$, Maxim Yermokhin ${ }^{3}$, Johannes Edvardsson ${ }^{4}$, Ando Lilleleht ${ }^{1}$, \\ Andres Kiviste ${ }^{1}$, Tanel Kaart ${ }^{5}$, Sandra Metslaid ${ }^{1}{ }^{(D}$, Arvo Järvet ${ }^{2}$ and Maris Hordo ${ }^{1}$ \\ 1 Institute of Forestry and Rural Engineering, Estonian University of Life Sciences, Kreutzwaldi 5, 51006 Tartu, \\ Estonia; ando.lilleleht@emu.ee (A.L.); andres.kiviste@emu.ee (A.K.); Sandra.Metslaid@emu.ee (S.M.); \\ Maris.Hordo@emu.ee (M.H.) \\ 2 Institute of Ecology and Earth Sciences, University of Tartu, Vanemuise 46, 51003 Tartu, Estonia; \\ sandra.toomik@ut.ee (S.T.); arvo.jarvet@ut.ee (A.J.) \\ 3 Institute of Experimental Botany of the National Academy of Science of Belarus, Academicheskaya 27, \\ 220072 Minsk, Belarus; yermaxim@yahoo.com \\ 4 Department of Geology, Lund University, Sölvegatan 12, SE-223 62 Lund, Sweden; \\ johannes.edvardsson@geol.lu.se \\ 5 Institute of Veterinary Medicine and Animal Sciences, Estonian University of Life Sciences, Kreutzwaldi 62, \\ 51006 Tartu, Estonia; Tanel.Kaart@emu.ee \\ * Correspondence: aleksei.potapov@emu.ee
}

Received: 7 October 2019; Accepted: 27 November 2019; Published: 2 December 2019

check for updates

\begin{abstract}
Fourteen tree-ring chronologies developed from 788 peatland Scots pines sampled at sites in Estonia, Belarus and Sweden were compared for common growth trends and possible links to regional climate dynamics. Several synchronous growth release events were detected, especially during the 1910s, 1930s, and around 1970 and 1990, indicating that hydrological shifts and associated tree growth responses have been governed by similar forcing mechanisms, at least during the 20th century. In general, the best agreements were observed between the tree populations from Estonia and Belarus, but synchronous growth changes could also be detected between the Swedish and Estonian material. Trends detected in single tree-ring chronologies may be linked to local peatland management or land-use changes, whereas common variations detected at multiple sites are more likely linked to hydrological changes in the peatlands associated with regional climate dynamics. Understanding the links between climate and processes that involve peatland hydrology and vegetation responses is important since peatland ecosystems are key players in the global carbon cycle.
\end{abstract}

Keywords: peatlands; Scots pine; Pinus sylvestris; hydrological variability; growth release; dendrochronology

\section{Introduction}

Peatland ecosystems are characterized by high soil moisture and partially decomposed vegetation accumulated as peat in soil layers [1]. Hydrological variability of peatlands depends on various climatic factors and affects peatland vegetation and carbon storage dynamics [2-4]. Even in their natural state, peatlands are considered complex and dynamic ecosystems, but peatland management or land-use changes may induce even more rapid shifts affecting local hydrology [1]. Throughout human history, peat and peatlands have been utilized for a wide range of purposes including fuel for heating, agriculture, timber production, and plantation soils improvement. Such activities often 
involved management of the hydrological regime, resulting in degraded or converted ecosystems with altered biodiversity and carbon uptake [1], although disturbed areas with less evident effects of human impact also exist; e.g., in the case of failed or insufficient site modification. Globally, the share of artificially drained peatlands is about 6\% [5], but for Fennoscandia and the Baltics this figure is higher and the number of peatlands disturbed by ditching as a silvicultural treatment is substantial [1]. The area of peatlands drained for forestry varies by country, and in some regions, a considerable amount of commercial forests is located in such sites. By way of example, around $20 \%$ of the forest stands in Estonia are growing on organic soils [6].

Numerous factors affect tree growth and high groundwater levels (GWL) limit growth in peatlands due to poor soil aeration and low nutrient availability [7-11]. As a consequence, drainage has been practiced (most intensively during the 20th century) to improve the conditions for peatland tree growth [1,12,13].

Tree-ring data are useful for exploring the effects of soil moisture status and several other factors on tree and forest growth. High-frequency signals extracted from tree-ring series can be utilized to address relationships with short-term climatic variability, and a number of studies have identified links between temperature and precipitation on tree radial growth at an annual scale using ring-width data of various tree species in Estonia [14-18] and other countries in the Baltic region [19-22]. Low-frequency signals contained in ring-width series can be associated with tree size or age and various endogenous and exogenous disturbances [23]. In peatlands, these signals can be linked to long-term GWL fluctuations and corresponding changes in site conditions related to climatic reasons or induced by human activities; e.g., site modification by ditching affects the long-term variability of tree radial increment, introducing a positive trend for several post-drainage years [7,12].

The processing of tree-ring series to explore climate-growth relationships often includes the removal of the mid- and/or low-frequency component contained in such data through the detrending (standardization) procedure [24]. However, in the case of peatland sites, it was found that at an annual time scale, correlations between tree growth and climatic variables are lower compared to those derived from tree-ring data originating from the same species on mineral soils $[2,19,25]$. Hydrological feedbacks and slow responses of GWL to short-term climatic variability can be a result of weak correlations in the case of high-frequency signals, whereas mid- or low-frequency signals can still be associated with climatic fluctuations and variability in peatland hydrology at a multi-annual scale $[2,3,19,26,27]$.

Complex interactions among climate, peatland hydrology, and tree growth may compromise the interpretation of climatic signals contained in tree-ring series. Despite this, several studies have shown that such data can be used to study climatic effects on the growth of peatland trees and hydrological variability $[2,10]$. However, for such a purpose, variations in tree growth related to land-use changes, ditching, and other man-made disturbances must be identified before climate dynamics can be modeled.

Assessing climatic effects on peatland hydrology is essential for evidence-based planning and management of peatlands for forestry (e.g., planning of ditch network maintenance) as well as peatland restoration, also considering climate mitigation and other ecosystem services. GWL is an important variable for modeling processes related to peatland ecology, hydrology, biogeochemistry, and greenhouse gas fluxes $[3,4]$. Continuous long-term instrumental series of GWL data from peatlands are very scarce, and there are few records as long-term as the records from Männikjärve bog in Estonia, which span from 1956 to the present [28]. However, several proxies, including tree-ring data, can be useful in acquiring reconstructions of past hydrological variability for a better understanding of current trends and predicting possible future scenarios. Understanding and predicting peatland hydrology under changing climatic conditions is of great importance since around one-third of the world's soil carbon pool is stored in peatland soils [1].

The objective of this study was to explore the possibility of detecting a regional climatic signal in mid- and long-term growth trends of peatland Scots pine (Pinus sylvestris L.) in Belarus, Estonia and Sweden, focusing on the 20th century. We examined the following hypotheses: (1) the effects of large-scale climatic drivers result in synchronous long-term growth trends of trees from various peatland sites within a region; (2) climatic signals contained in mid- and low-frequency (multi-annual) variability 
in ring-width series can serve as a proxy for reconstructing peatland hydrology; and (3) changes in the long-term dynamics of tree radial growth in peatlands are not exclusively associated with man-made disturbances, such as ditching, but also with GWL fluctuations driven by climatic variability. Similarly, to the effect of ditching, climatically induced lowering of GWL can result in an increased growth rate of trees.

\section{Materials and Methods}

\subsection{Study Sites and Tree-Ring Data}

Available tree-ring data collected for the current study were compiled from sites (Table 1, Figure 1c) located in Belarus [29,30], Sweden [25], and Estonia [31,32]. The study areas represent different wetland types (fen, transitional bog, or raised bog) with different productivity and management histories, but all were colonized by Scots pine. On several sites, the hydrological regime is or has been regulated by networks of drainage ditches, especially in northeast and southeast Estonia, but also (to some extent) in southwest Belarus. Site modification by drainage was initiated at different times; exact years (according to archived documents and construction plans) are available only for the Ongassaare area (northeast Estonia), where the ditch network was constructed during 1970-1973. For other sites, information is absent or not specific (e.g., ditches are present on forest maps from 1922 for the Kanajalasoo area in southeast Estonia).

Table 1. Characteristics of selected study areas and sampled trees.

\begin{tabular}{|c|c|c|c|c|c|c|c|c|c|c|c|c|c|}
\hline \multicolumn{4}{|c|}{ Study Area } & \multicolumn{2}{|c|}{ Coordinates } & \multirow{2}{*}{ Type } & \multirow{2}{*}{$\begin{array}{l}\text { Drainage } \\
\text { Ditches }\end{array}$} & \multirow{2}{*}{$\mathbf{N}$} & \multirow{2}{*}{$\begin{array}{l}\mathrm{D}^{2} \\
(\mathrm{~cm})\end{array}$} & \multirow{2}{*}{$\begin{array}{l}\text { Age }^{2} \\
\text { (year) }\end{array}$} & \multicolumn{2}{|c|}{ TRW (mm) } & \multirow{2}{*}{$\begin{array}{l}\text { First } \\
\text { Year }\end{array}$} \\
\hline nr. & & egion & Name & Lat & Long & & & & & & Mean & SD & \\
\hline 1 & \multirow{5}{*}{ صृ } & $\mathrm{N}$ & Berezinsky & 54.75 & 28.29 & $\mathrm{r}$ & Absent & 45 & 10.6 & 121 & 0.45 & 0.35 & 1826 \\
\hline 2 & & NW & Milashki & 55.43 & 27.02 & $t$ & Distant & 40 & 17.6 & 166 & 0.55 & 0.33 & 1787 \\
\hline 3 & & S & Aziarany & 51.95 & 27.87 & $\mathrm{r}$ & Distant & 16 & 13.1 & 103 & 0.70 & 0.51 & 1852 \\
\hline 4 & & $\mathrm{NE}$ & Zorycy & 54.21 & 28.92 & $t$ & Absent & 24 & 22.9 & 158 & 0.78 & 0.45 & 1786 \\
\hline 5 & & SW & Białowieża & 52.88 & 24.02 & $\mathrm{f}, \mathrm{t}, \mathrm{r}$ & $*$ & 170 & 26.0 & 148 & 1.01 & 0.62 & 1769 \\
\hline 6 & \multirow{5}{*}{ 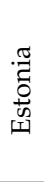 } & $\mathrm{N}$ & Ongassaare & 59.16 & 27.43 & $\mathrm{f}, \mathrm{t}$ & Present & 160 & 26.6 & 97 & 1.55 & 0.73 & 1786 \\
\hline 7 & & SE & Kanajalasoo & 58.31 & 27.30 & $\mathrm{t}$ & Present & 39 & 16.2 & 119 & 0.73 & 0.39 & 1796 \\
\hline 8 & & $\mathrm{NE}$ & Selisoo & 59.18 & 27.28 & $\mathrm{r}$ & Some plots & 69 & 13.1 & 105 & 0.63 & 0.28 & 1851 \\
\hline 9 & & SE & Ullika & 58.25 & 27.35 & $\mathrm{r}$ & Some plots & 61 & 10.6 & 102 & 0.55 & 0.21 & 1874 \\
\hline 10 & & W & Tuhu & 58.58 & 23.84 & $\mathrm{r}$ & Some plots & 49 & 13.3 & 128 & 0.52 & 0.28 & 1856 \\
\hline 11 & \multirow{4}{*}{ 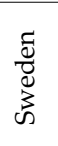 } & $S$ & Store & 57.23 & 13.92 & $\mathrm{r}$ & Absent & 49 & 16.5 & 94 & 0.89 & 0.43 & 1877 \\
\hline 12 & & S & Saxnäs & 56.85 & 13.45 & $\mathrm{r}$ & Absent & 20 & 12.4 & 89 & 0.73 & 0.36 & 1893 \\
\hline 13 & & $S$ & Buxabygds & 56.80 & 14.22 & $\mathrm{r}$ & Distant & 21 & 17.0 & 90 & 0.99 & 0.51 & 1905 \\
\hline 14 & & $S$ & Hästhults & 56.70 & 13.48 & $\mathrm{r}$ & Absent & 25 & 15.3 & 57 & 1.33 & 0.96 & 1942 \\
\hline
\end{tabular}

Type-type of peatland sites ( $\mathrm{f}-\mathrm{fen}, \mathrm{t}$-transitional bog, $\mathrm{r}$-raised bog), N-number of trees, D-mean diameter inside bark, TRW—-tree-ring width, SD—standard deviation, First year-the year from which the sample size of the ring-width dataset is at least 3 trees (the last year in the time span of tree-ring data varies between 2006 and 2016). ${ }^{1}$ Present-sites where the hydrological regime is or was actively managed by ditching, Absent—undrained sites, Distant-not completely undisturbed by ditching, but the effect of drainage is believed to be minor due to the distance to the nearest ditch, Some plots-sample plots are located along a transect perpendicular to the drainage ditch, therefore the plots can be considered to be in the Present or Distant category depending on the distance to the ditch (distance varies between 0 and $700 \mathrm{~m}$ ), *-ditches are present in the case of some of the sample plots within a larger study area. ${ }^{2}$ Mean tree diameter (inside bark) and age are estimated at 1.3 (in the study areas 1 to 7 ) or $0.3-0.5 \mathrm{~m}$ (in the study areas 8 to 14 ) above the root collar.

The tree sampling areas (Table 1) at several sites in Sweden and north Belarus are believed to be undisturbed or negligibly affected by ditching (sites 11,12,14, and 1, 4, respectively). Other sites $(2,3,5,8,9,10$, and 13) were located near artificially drained areas, but they were not subject to direct modification by drainage. The ditches present in the surroundings were constructed to regulate the hydrological regime (e.g., by functioning as a cut-off ditch) and generate more productive forests around the peatlands. It was not possible to expect that tree growth at these sites was completely unaffected by ditching; however, the drainage effect can still be assumed to be negligible [33,34] since the nearest ditches were located at a considerable distance from the sample plots (up to $700 \mathrm{~m}$ ). 
Living Scots pine trees were selected within the study areas using various approaches (i.e., randomly or along a transect) according to the methodologies of the research projects. Selected trees were sampled by taking two increment cores at $1.3 \mathrm{~m}$ (study areas 1 to 7 ) or at $0.3-0.5 \mathrm{~m}$ above the root collar (study areas 8 to 14). Core samples were processed using standard dendrochronological equipment and techniques [35] and ring-width measurements were done with a precision of $0.01 \mathrm{~mm}$. The quality of cross-dated tree-ring series was assessed using COFECHA software (version 6.06, Lamont-Doherty Earth Observatory, Palisades, NY, USA) [36]. The compiled data included 788 trees in total.
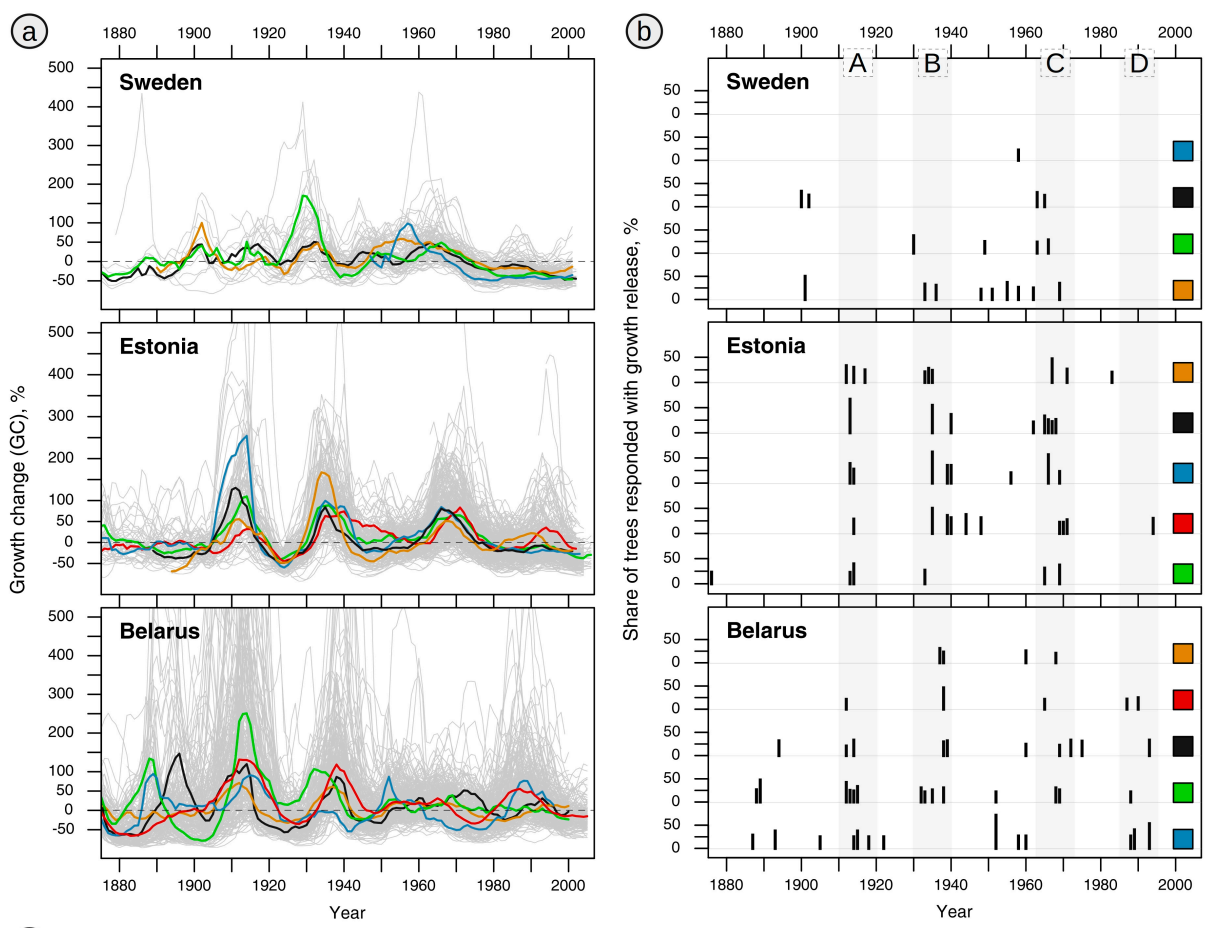

(c)
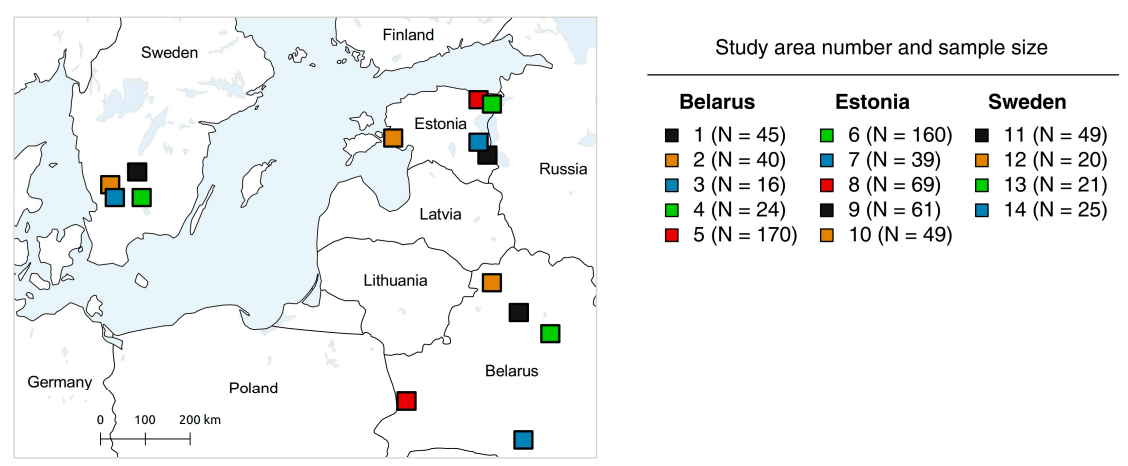

Figure 1. Changes in the radial growth of pine trees from different peatland sites in Sweden, Estonia and Belarus during the 20th century. (a) Relative growth change (\%GC) series of individual trees (grey lines) and mean \%GC series for each study area. (b) Number (\%) of trees that responded with growth release in each study area at a certain time period; values lower than $20 \%$ were filtered out and are not present in the plot. The letters A-D highlight four periods associated with synchronous growth release events. (c) The locations of selected study areas (Table 1) are marked with black, yellow, blue, green and red squares. The colours are unique within a country; the same ones are used in parts $(\mathbf{a}, \mathbf{b})$ of the figure.

\subsection{Estimating the Timing of Growth Release Events}

Ring-width data were used to analyze long- and mid-term (multi-annual to decadal) growth trends of peatland trees. The radial growth averaging method proposed by Nowacki and Abrams [37] was applied to reconstruct and compare disturbance dynamics in different distant peatland sites and 
estimate the timing of events followed by an abrupt increase in the growth rate of trees (growth release events). This method was developed for exploring long-term trends in forest stand dynamics [38] and was found to be applicable in evaluating the canopy disturbance history [37,39-41], also was suggested to be helpful [40] in estimating ground-level disturbances caused by fire. Various factors can initiate changes of different intensity in tree growth dynamics that can be detected using this technique. Since high soil moisture, but not light, was the major growth-limiting factor throughout the lifetime of sampled peatland trees, in the current study, growth release events were hypothesized to be related to long-term fluctuations of GWL driven by climatic variability at a multi-annual scale.

Percent growth change (\%GC) values were calculated for each tree in the data set and each year in ring-width series according to the following equation [37]:

$$
\% \mathrm{GC}=\frac{\mathrm{M}_{2}-\mathrm{M}_{1}}{\mathrm{M}_{1}} \times 100,
$$

where $M_{1}$ is the average growth of the preceding period (target year is included) and $M_{2}-$ mean ring-width during the subsequent period (target year is excluded). Series of \%GC values (\%GC series) of individual trees and mean \%GC series for each study area, also the number (share) of trees that responded with a growth release were calculated using functions of TRADER (version 1.2-3) [42] and dplR (version 1.7.0) [43] packages of $R$ software (version 3.5.3; R Foundation for Statistical Computing, Vienna, Austria) [44]. Default values of 10 years were used as the lengths of $M_{1}$ and $M_{2}$ periods. A 10-year span was suggested to be suitable for filtering out the responses to short-term climatic variability while keeping the longer-term signals [37]. Various numerical values describing a growth release as major or moderate were suggested in previous studies [37-39]. A minimum threshold of $25 \%$, as suggested by Abrams et al. [38], was set as a criterion for detecting growth release events and no distinction between major or moderate releases was made.

The raw ring-width data were used in preference to detrending procedures frequently applied in tree-ring studies [24] in order to preserve the mid- and low-frequency variability in the series. Several detrending methods were tested for calculating \%GC values based on ring-width indices, but all of them lost the signal of interest (to a lesser or greater extent) and therefore shortened the list of detected growth release events (Figure S1). Removing the trend associated with tree age (i.e., with biological or geometric effects) was not necessary since it was seldom present in the sampled trees (Figure S2). Furthermore, at the studied period the trees were mostly of older age when this trend is usually weak; the presence of a decreasing growth trend at the beginning of the ring-width series should not produce any artifacts (additional growth releases) in \%GC data [42].

\subsection{Climatic Data}

Time series of the meteorological drought metric PDSI (Palmer Drought Severity Index) were used in order to assess possible effects of climatic variability on long- and mid-term growth trends of the peatland pines. The PDSI was designed to vary around zero, with negative and positive values representing dry and wet conditions, respectively, whereas absolute values above 4.0 correspond to extreme situations [45]. Self-calibrating PDSI (scPDSI) time series of monthly mean values for April, May, June, and July, the mean of scPDSI for the growing period (April-September) and for a year (October-September) were extracted from the gridded data set [46,47] of KNMI Climate Explorer (The Royal Netherlands Meteorological Institute, De Bilt, Netherlands) [48] according to the location of each study area. Because of the resolution of the dataset $\left(0.5^{\circ}\right.$ longitude by $0.5^{\circ}$ latitude), it was possible to download unique scPDSI time series for 11 out of the 14 study areas, therefore study areas 6,7 , and 12 shared the same scPDSI values as in the case of 8,9, and 14, respectively. Monthly data of scPDSI were available for the period of January 1901 to December 2016. Compared to the original index, the self-calibrating PDSI allows a better spatial comparison between different regions [49].

Similarities between the study areas in long- and mid-term trends of scPDSI time series were also checked, as in the case of tree radial growth. Differences between scPDSI means (PDSI diff $_{\text {variable) }}$ 
were calculated for each year of available time span of scPDSI series as follows in order to transform scPDSI data to a format similar to \%GC series [37]:

$$
\mathrm{PDSI}_{\text {diff }}=\mathrm{P}_{2}-\mathrm{P}_{1}
$$

where $P_{1}$ is the mean scPDSI index of the preceding period (target year is included) and $P_{2}-$ of subsequent period (target year is excluded). The length of the period of $\mathrm{P}_{1}$ and $\mathrm{P}_{2}$ was set as the one in the case of $\mathrm{M}_{1}$ and $\mathrm{M}_{2}$ in \%GC calculations-i.e., 10 years. The resulting PDSI diff $_{\text {fime series described }}$ climatic trends, indicating changes towards wetter or drier future growing conditions in the case of positive or negative values, accordingly. Relationships between mean \%GC series and PDSI ${ }_{\text {diff }}$ values of April, May, June, July, and the growing period or year for each study area were checked visually and according to calculated correlation coefficients. The temporal stability of the linear relationships was also assessed using a moving correlation analysis. Correlation coefficients were calculated for a

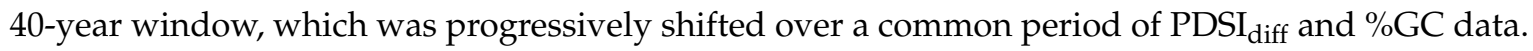

\section{Results}

\subsection{Radial Growth Trends}

Growth release events were dated for each study area according to \%GC series (Figure 1a) when the majority of the trees showed changes in radial growth dynamics (Figure 1b). Common patterns in mid- and long-term (multi-annual to decadal) growth trends of Scots pine trees from various peatland sites were noted for the 20th century. The synchronicity of mean \%GC series is evident in the case of sites within Estonia, whereas the variability among the study areas in Belarus was greater. Periods showing disagreement in mean \%GC series were also noted among the study areas in Sweden (Figure 1a). In the case of different sites, the onset of periods associated with improved growth rates was mostly identified in ring-width data during the time intervals: 1910-1915, mid to late 1930s, as well as around 1970 and 1990 (time period A, B, C and D, Figure 1b).

The \%GC data suggest that radial growth dynamics were similar in Estonia and Belarus, especially in the first half of the 20th century. Highly synchronous growth release events were dated for trees in both regions during the periods A, B and C (Figure 1b). Some trees, especially those in Belarus, also responded during the time interval D. In comparison, the number of such trees in Estonia is lower, but present, for example, in northeast Estonia (study area 8). Growth release events can be detected around period D also in west Estonia (study area 10), but the timing is earlier (1983) in comparison to the other sites (Figure 1b).

The south Swedish \%GC data exhibit slightly different growth dynamics compared to the trees from Estonia and Belarus. However, the Swedish trees still show growth releases during the time intervals B and C, although there are fewer sites with responded trees in period B, and the dated events are mainly distributed in the first half of the time intervals. During time periods A and D, no significant changes in tree growth dynamics were detected (Figure 1b). However, according to the \%GC series of a small number of trees in study area 11 (Store mosse), it is still possible to suggest a growth release event during time interval D (Figure 1a).

\subsection{Climatic Variability and Growth Release}

Synchronicity in the timing of growth release events among multiple sites (Figure 2) suggests

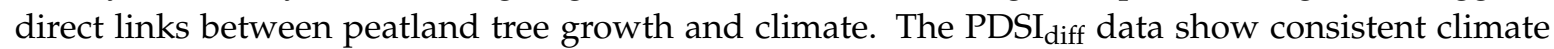
trends for almost all the study areas from the beginning of the 20th century until the 1960s-1970s, but indicate disagreement during later decades (Figure 2). Results from the correlation analysis show a

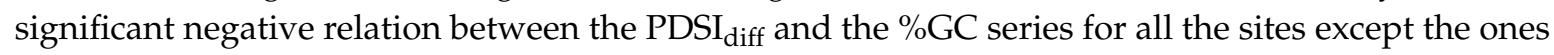
in south and southwest Belarus (Figure 3, Table 2). The timing of the growth release events mostly corresponds to the periods with lower values of PDSI diff $_{\text {(Figure 2). }}$ 


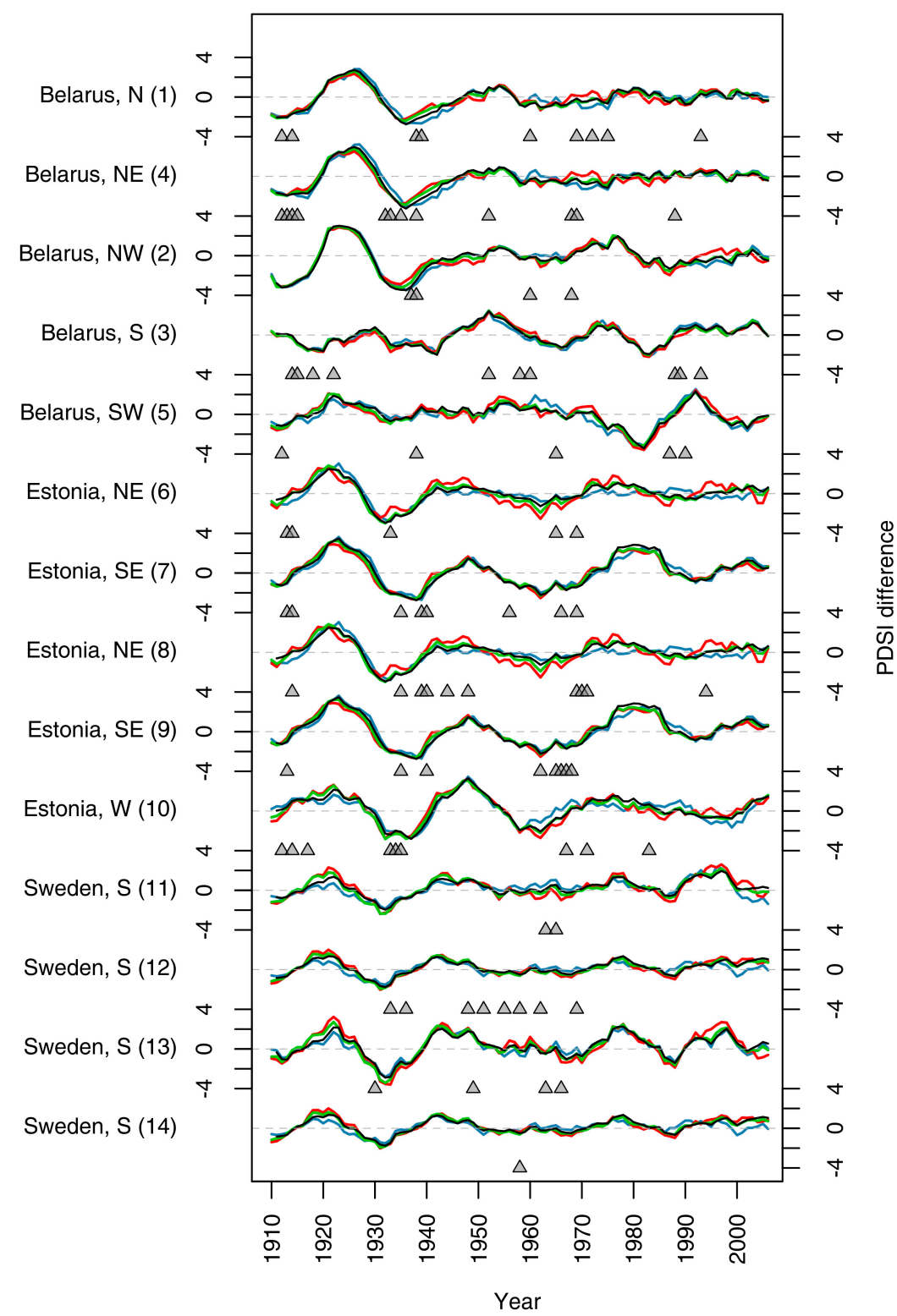

Figure 2. PDSI $_{\text {diff }}$ time series (lines) and year of growth release events (triangular symbol) in each study area (country, region, also study area number (in parentheses) are shown on the left). Different

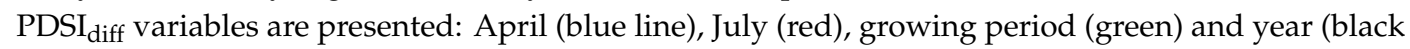

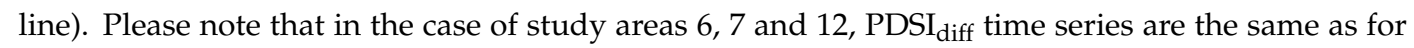
study areas 8,9 and 14 , respectively (due to the resolution of the used gridded dataset). 


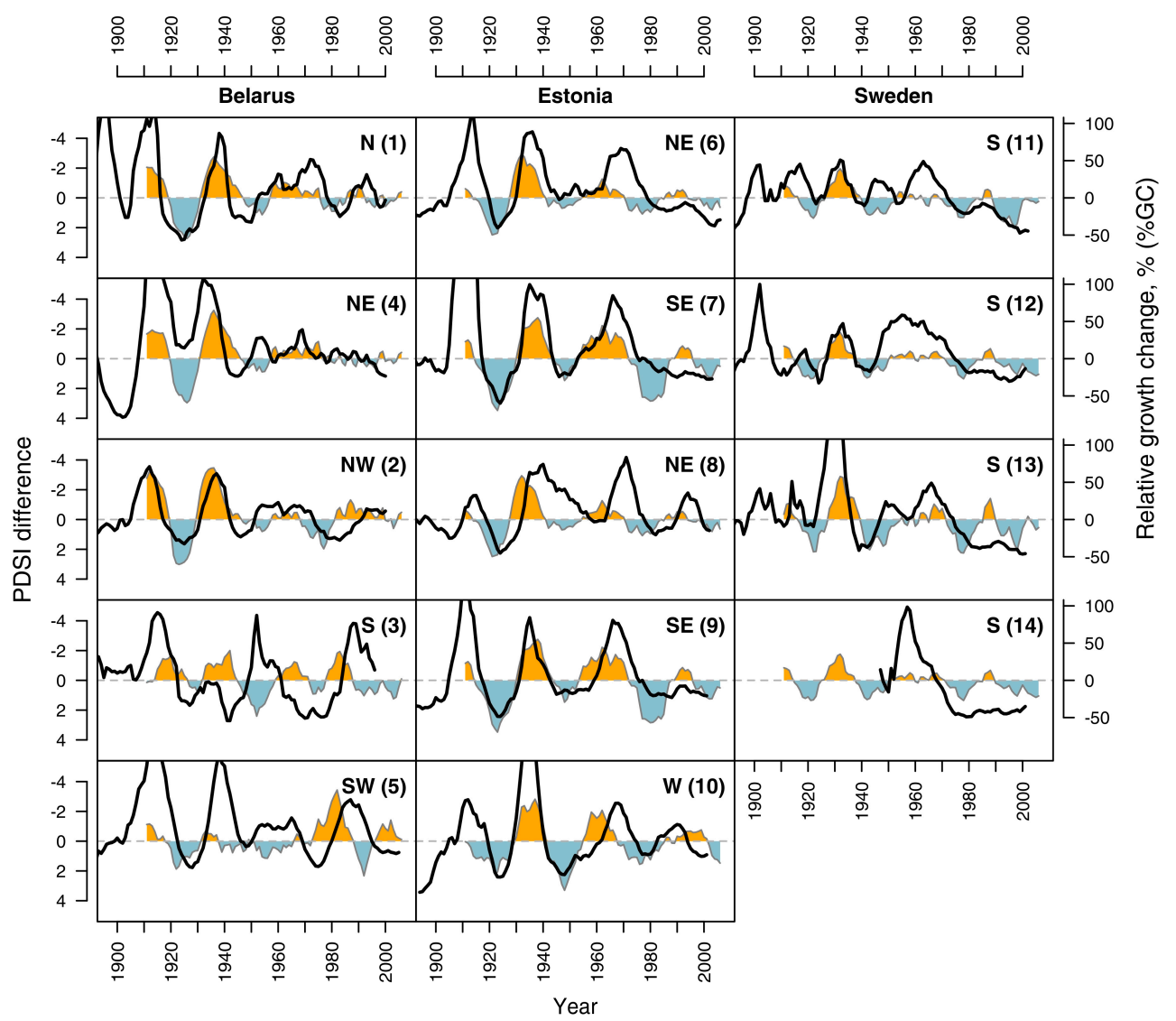

Figure 3. Time series of mean \%GC series (black line) and yearly PDSI difference (PDSI ${ }_{\text {diff; }}$ shaded area) for each study area. The region and number (in parentheses) of the study area are shown in the right

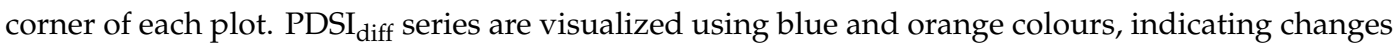
towards wetter or drier future growing conditions-positive and negative values, respectively. Please note that the axis for PDSI ${ }_{\text {diff }}$ is reversed; in the case of study areas 6, 7 and 12, PDSI diff time series are the same as for study areas 8,9 and 14, respectively (due to the resolution of the used gridded dataset).

Table 2. Correlation coefficients (r) and adjusted $R^{2}$ for the relationships between mean \%GC and PDSI $_{\text {diff }}$ of April, May, June, July, the growing period (from April to September) and year (from October of the previous year to September of the current year) for each study area.

\begin{tabular}{|c|c|c|c|c|c|c|c|c|c|c|c|c|c|c|}
\hline \multicolumn{3}{|c|}{ Study Area } & \multicolumn{2}{|c|}{ April } & \multicolumn{2}{|c|}{ May } & \multicolumn{2}{|c|}{ June } & \multicolumn{2}{|c|}{ July } & \multicolumn{2}{|c|}{$\begin{array}{c}\text { Growing } \\
\text { Period }\end{array}$} & \multicolumn{2}{|c|}{ Yearly } \\
\hline nr. & & Region & $r$ & $R^{2}$ & $\mathbf{r}$ & $R^{2}$ & $\mathbf{r}$ & $R^{2}$ & $\mathbf{r}$ & $R^{2}$ & $\mathbf{r}$ & $R^{2}$ & $\mathbf{r}$ & $R^{2}$ \\
\hline 1 & & North & $-0.72 *$ & $0.51 *$ & $-0.71 *$ & $0.50 *$ & $-0.70 *$ & $0.49^{*}$ & $-0.60 *$ & $0.36^{*}$ & $-0.71 *$ & $0.50 *$ & $-0.72 *$ & 0.51 * \\
\hline 2 & 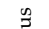 & Northwest & $-0.68^{*}$ & $0.46^{*}$ & $-0.67 *$ & $0.45 *$ & $-0.68^{*}$ & $0.46^{*}$ & $-0.57^{*}$ & $0.32 *$ & $-0.67^{*}$ & $0.44 *$ & $-0.72 *$ & $0.51 *$ \\
\hline 3 & Е్త్ర & South & 0.17 & 0.02 & 0.18 & 0.02 & 0.12 & 0.00 & 0.12 & 0.00 & 0.16 & 0.02 & 0.20 & 0.03 \\
\hline 4 & Ф & Northeast & $-0.37^{*}$ & $0.13^{*}$ & $-0.46^{*}$ & $0.21 *$ & $-0.44^{*}$ & $0.19 *$ & $-0.46^{*}$ & $0.20 *$ & $-0.46^{*}$ & $0.20 *$ & $-0.43^{*}$ & 0.18 * \\
\hline 5 & & Southwest & 0.00 & -0.01 & -0.06 & -0.01 & 0.01 & -0.01 & -0.02 & -0.01 & -0.02 & -0.01 & -0.04 & -0.01 \\
\hline 6 & & Northeast & $-0.60 *$ & $0.35^{*}$ & $-0.60 *$ & $0.35 *$ & $-0.33 *$ & $0.10^{*}$ & $-0.30 *$ & $0.08 *$ & $-0.42 *$ & $0.17^{*}$ & $-0.50 *$ & 0.24 * \\
\hline 7 &.$\Xi$ & Southeast & $-0.60 *$ & $0.35 *$ & $-0.62 *$ & $0.38^{*}$ & $-0.53 *$ & 0.27 * & $-0.53 *$ & $0.27 *$ & $-0.55 *$ & 0.30 * & $-0.57^{*}$ & $0.32 *$ \\
\hline 8 & క్తే & Northeast & $-0.40 *$ & $0.15^{*}$ & $-0.35 *$ & $0.11 *$ & 0.05 & -0.01 & 0.02 & -0.01 & -0.14 & 0.01 & $-0.26^{*}$ & $0.06 *$ \\
\hline 9 & 藏 & Southeast & -0.68 * & $0.45^{*}$ & $-0.70 *$ & $0.48^{*}$ & $-0.64 *$ & $0.40 *$ & $-0.63 *$ & $0.39 *$ & $-0.65 *$ & $0.42 *$ & $-0.66^{*}$ & 0.44 * \\
\hline 10 & & West & $-0.54^{*}$ & $0.28 *$ & $-0.61 *$ & $0.37 *$ & $-0.60 *$ & $0.35^{*}$ & $-0.65^{*}$ & $0.41 *$ & $-0.66^{*}$ & 0.42 * & $-0.65 *$ & 0.41 * \\
\hline 11 & & South & $-0.42 *$ & $0.17^{*}$ & $-0.38 *$ & $0.13 *$ & $-0.48 *$ & $0.22 *$ & $-0.56^{*}$ & $0.30 *$ & $-0.48 *$ & $0.22 *$ & $-0.53^{*}$ & $0.27 *$ \\
\hline 12 & $\frac{\bar{g}}{0}$ & South & $-0.36^{*}$ & $0.12 *$ & $-0.41 *$ & $0.16^{*}$ & $-0.41 *$ & $0.16^{*}$ & $-0.42 *$ & $0.16^{*}$ & $-0.44 *$ & 0.19 * & $-0.46^{*}$ & 0.20 * \\
\hline 13 & $\overbrace{3}^{\varpi}$ & South & $-0.58^{*}$ & $0.32 *$ & $-0.53 *$ & $0.27 *$ & $-0.58^{*}$ & $0.33 *$ & $-0.53 *$ & $0.27 *$ & $-0.58 *$ & $0.33 *$ & $-0.54 *$ & $0.29 *$ \\
\hline 14 & के & South & $-0.46^{*}$ & $0.20 *$ & $-0.29 *$ & $0.08^{*}$ & $-0.25 *$ & $0.05^{*}$ & -0.13 & 0.01 & $-0.25 *$ & $0.05 *$ & $-0.28 *$ & 0.07 * \\
\hline
\end{tabular}

Absolute values of the correlation coefficients of significant linear models varied from 0.25 to 0.72 , whereas the adjusted $R^{2}$ ranged from 0.05 to 0.51 . The highest $R^{2}$ values described relationships 


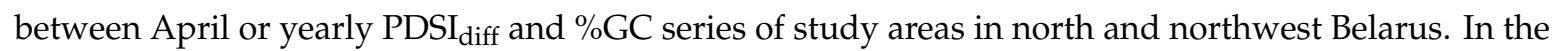
case of study area 14 in Sweden and 8 in northeast Estonia, $R^{2}$ is below or around 0.1 for almost all of the PDSI diff $_{\text {variables, except for April PDSI }}$ diff. Low $R^{2}$ values were also detected for June and July PDSI $_{\text {diff }}$ in drained sites of northeast Estonia (study area 6), but it reached 0.35 for April and May

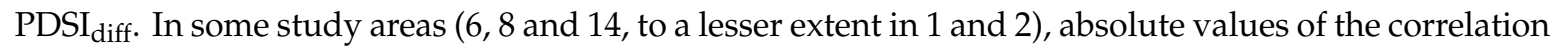
coefficient showed a decreasing trend from early spring to mid-summer. Stronger relationships were associated with April and May (or yearly) values of PDSI $\mathrm{diff}_{\text {; }}$ however, that was not the case in general. There were also examples of the opposite situation; for instance, study areas 10 and 11, where the highest absolute values of the r coefficient were reached for July PDSI diff (Table 2).

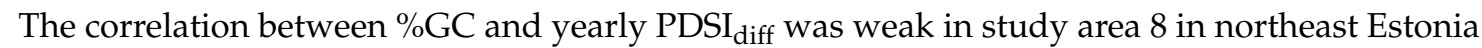
in comparison to drained sites of the same region (study area 6). However, according to the time series of the variables (Figure 3), there seemed to be a lag between the \%GC and yearly PDSI diff $_{\text {series, }}$ which could account for the lower $r$ coefficient. The same does not hold when comparing drained and other peatland sites of southeast Estonia (study areas 7 and 9), as no lag was detected between \%GC

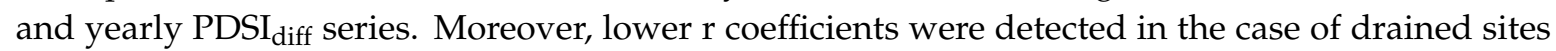
compared to natural ones, even though the difference is not particularly large (Figure 3, Table 2).

Non-significant relationships were found for June, July, and growing period PDSI diff $_{\text {in northeast }}$

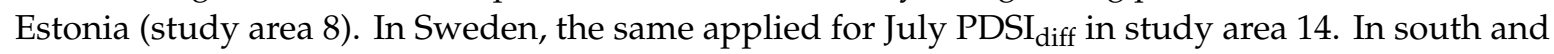
southwest Belarus (study areas 3 and 5), $p$-values were lower than 0.05 for all of the PDSI diff variables

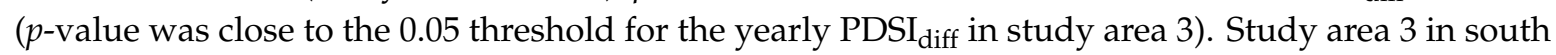
Belarus was exceptional, since it was the only case when the correlation was positive for all PDSI diff variables. However, the number of sampled trees there (16) was the lowest of all the study areas (Table 1).

The relationship between \%GC and PDSI ${ }_{\text {diff }}$ was seldom stable throughout the 20th century, and the varying $r$ coefficient showed a disagreement between the time series towards the end of the studied period (Figure 4 gives an example of the yearly PDSI $\mathrm{diff}_{\text {). The }}$. There shifts in the correlation sign from negative to positive in northeast and west Estonia, as well as southwest Belarus. The correlation sign changed from positive to negative in study area 12 in south Sweden. In northeast and northwest Belarus, the relationship became weaker and non-significant during the second half of the 20th century. However, the opposite trend was present in south Sweden; the absolute value of the correlation coefficient in study area 11 increased at that time. In south Belarus, the $r$ coefficient was constantly positive and significant for most of the studied period of time, but the value of the coefficient slightly varied and was higher in the middle of the period. There were also some sites where the negative correlation was more stable and stayed significant throughout most of the time period; i.e., north Belarus, northeast and southeast Estonia (study areas 1, 6 and 7), and, to a lesser extent, study area 9 (Figure 4). 

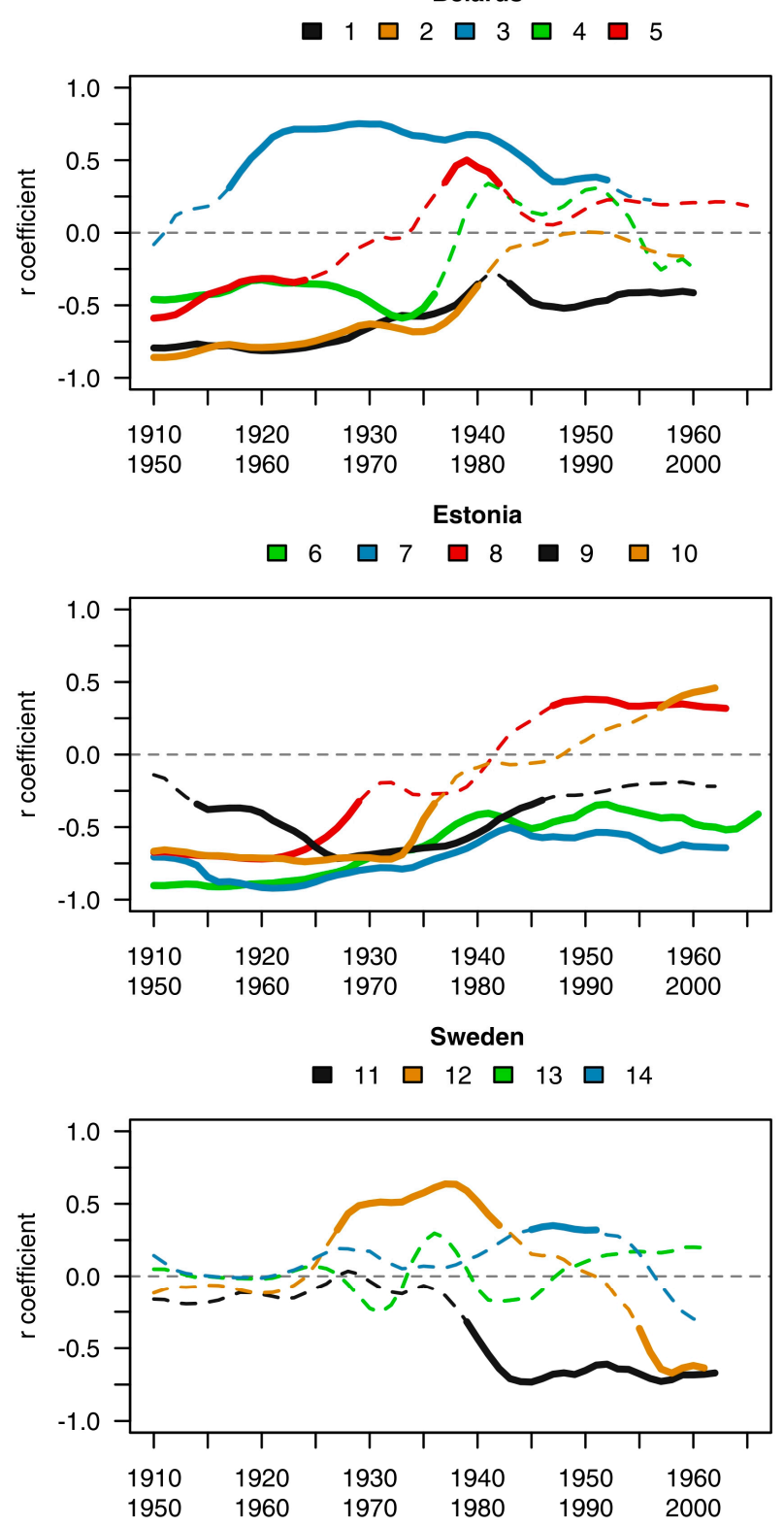

Figure 4. Temporal stability of the relationship between \%GC and yearly PDSI diff $_{\text {in }}$ study areas of Belarus, Estonia and Sweden. Each line represents changing values of the correlation coefficient, calculated for a progressively shifted 40-year time window (upper and lower labels on the x-axis). Solid lines indicate a significant relationship, dashed lines illustrate $p>0.05$. The colours are unique within a country, the same ones are used in Figure 1.

\section{Discussion}

Although study areas varied with regard to fertility, management history, and hydrological regime (e.g., both drained and undrained sites were used), there were common patterns in longand mid-term trends of tree radial growth (derived from tree-ring data in a form of \%GC series). This suggests that the pine trees were experiencing synchronous periods of depressed and improved growth conditions throughout the 20th century, especially in the case of peatland sites in Estonia and Belarus. Similarities between the study areas in timing of growth release events indicate that changes in growth dynamics were driven by climatic variability rather than by a response to more local disturbances such as forest management activities. It is highly unlikely that silvicultural treatments were applied in such a synchronized manner in sites so distant and diverse. Canopy disturbances by 
weather events (e.g., windthrow) can be synchronous on a larger scale, but this does not seem to be a probable driver considering the size and shape of trees and stand density in raised bogs.

The effect of ditching on tree radial growth was evident in ring-width data from drained sites [31]; however, changes identified as growth release events were initially related to other factors. In the case of study area 6 in northeast Estonia, for example, there was a traceable management history, but radial growth already started to improve 1-5 years before the construction of the ditch network in 1970; growth releases date back to 1965 and 1969 during time period C (Figure 1b). In such a case, the time period of increased tree radial increment induced by climatic variability overlaps with the post-drainage period, which is usually associated with improved forest growth [1].

\subsection{Comparison between Different Regions}

High soil moisture serves as a limiting factor not only for the growth of already established trees, but also for regeneration and survival of seedlings [8,50,51]. This limitation is apparent in studies exploring tree cover development and growth dynamics on peatland sites in the region. Results from several studies in bog sites of Latvia suggest a link between long-term changes in GWL and climatic variability [52-54]. Scots pine recruitment was enhanced for drained and undrained sites [54] during periods of favourable temperature and precipitation (warm summers, especially if precipitation was low). The effects caused by ditching were still important, but not always the key factor. The influence of artificial drainage can be also limited to a certain area within a bog complex. Čugunovs et al. [54] found that pine trees were recruited mostly during 1860-1870, 1940-1950, and 1960-1990 in the first study area, and during 1960-1980 in the second area. The following favourable (dry) periods were identified according to precipitation data: 1854-1881, 1887-1903, 1935-1946, 1966-1979, and 1997-2007 in the first study area; 1940-1961 and 1963-1979 in the second area. In addition, a decrease in GWL was observed during the 1960s and 1970s from instrumental data. Increased growth rates and positive pointer years were detected during almost all of the above-mentioned periods in tree-ring series from several bog sites of Latvia [52,53].

Peatlands in Lithuania were similar to Latvia in terms of tree recruitment patterns that were found to be climate-related; the spread of peatland trees was associated with warmer and drier climatic conditions [51]. Relatively dry periods of various duration were found to be characterized by an increase in tree radial growth, whereas depressed growth was recorded during relatively moist periods in several sites [2,55]. Dry periods were identified from precipitation and temperature time series in 1900-1920, from the late 1930s until the early 1940s, and from the late 1960s until the early 1980s.

Scots pine tree-ring chronologies developed by Smiljanić et al. [56] indicated improved growth conditions (lower than usual GWL) in a raised bog in Estonia (Männikjärve) during several periods: 1914-1928, after around 1939 and after 1971. These and similar results in peatlands of Latvia [52,54] and Lithuania [51] are comparable to the current study results, especially for the periods B and C (Figure 1b).

Peatland trees in south Sweden seemed to have slightly different patterns in growth dynamics during the early 20th century compared to Estonia and Belarus. For example, no pronounced growth release events were recorded during the 1910-1920 period (Figure 1b). Instead, growth release events were observed around the year 1900, which is only noted for the Swedish sites. According to Linderholm [19], Scots pine trees in peatland sites in the Scandinavian Mountains in central Sweden did experience increased growth rates during the 1910s. Still, assuming the same climatic drivers, contradictions in \%GC data from Swedish sites compared to Estonia and Belarus should indicate differences in climatic trends. However, climatic variability as represented by PDSI $_{\text {diff }}$ does not seem to be the case, since there is little difference evident (Figure 2).

Despite similar climatic trends, trees in south Sweden did not respond in the same manner as in

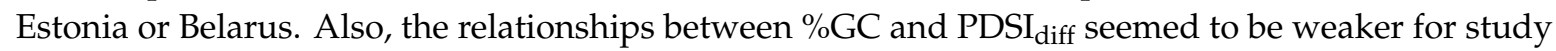
areas of Sweden, as the highest $R^{2}$ values usually were lower compared to Estonia or the northern part of Belarus, indicating that other, possibly non-climatic, factors affected tree radial growth dynamics. 
Still, growth dynamics of peatland trees in Sweden and Lithuania share common periodicities, not only during the 20th century, but since the mid-Holocene [57]. Similar growth patterns in Sweden and Lithuania were suggested to be related to hydrological trends, probably responding to large-scale climatic drivers such as North Atlantic Oscillation or Atlantic Multidecadal Oscillation [57].

\subsection{Links between Climate and Trends in Tree Radial Growth}

In peatlands, tree growth is limited by high soil moisture and therefore substantially depends on GWL [7-10,25,58]. Improved growth conditions for trees during post-drainage periods are a result of managing the hydrological regime by artificially lowering the GWL $[9,12,13]$. One can argue that changes in tree growth dynamics similar to the effect of ditching can also appear naturally due to climatic reasons, but in such cases the effect is likely to be more gradual and possibly of lower magnitude. Thus, growth release events should coincide with time periods characterized by drier climatic conditions which can result in a lower-than-average GWL.

The timing of growth release events identified in trees from Estonian sites coincides with the dry periods in the region during the 20th century as evidenced by long-term variability of water level changes recorded in Lake Peipsi, eastern Estonia. According to data presented by Jaani [59], decreasing trends in lake water-level fluctuations were recorded from the mid-1900s towards the year 1920, from the late 1920s until 1940 (the year of the lowest recorded water level), and from the late 1950s to the mid-1970s. These periods coincide with the time intervals A, B, and C (Figure 1b) characterized by increasing tree radial growth.

Climatic variability reflected in GWL fluctuations can also be monitored using drought indices. One of the options is PDSI, which has been shown to be correlated to GWL [60,61]. However, PDSI has limitations such as temporal resolution and this index better describes climatic drought rather than soil water balance [62,63]. Future applications should test other indices such as the monthly drought code [64], Standardized Precipitation Index [65,66] or Standardized Precipitation Evapotranspiration Index $[60,67]$ and various aggregation times of the indices. However, a drought index is often not enough to explain GWL fluctuations, and for more accurate and spatially specific predictions other variables, including soil-related characteristics, should be used.

Our results illustrate the relationship between PDSI diff $_{\text {and }} \% \mathrm{GC}$ variables, suggesting coherence in long-term trends of climatic variability affecting GWL and associated shifts in tree radial growth. Similar results were found by Nowacki and Abrams [37], however, the correlation was often weaker and of the opposite (positive) sign. Contrary to our findings, growth improvement was associated with wet periods since studied forest stands were growing on mineral sites where high soil moisture was not a limiting factor.

Linear models constructed in the current study were not meant for predictions or statistical inference; however, they still demonstrate a possibility of applying tree-ring data as a proxy for reconstructing trends in regional climate or hydrology of peatlands. Links between the peatland tree growth and GWL fluctuations have been noted in several studies [56,68], whereas the climatic signal contained in tree-ring series was found to better represent long-term trends than short-term climatic variability [2,19], possibly because hydrological responses of peatlands are slow and depend rather on low-frequency climatic fluctuations $[3,26,27]$. Similar trends in tree-ring data from peatlands have been found in other countries; for example in Switzerland, suggesting a regional climate-related signal contained in long-term radial growth patterns [8]. Leuschner et al. [69] described an agreement in low-frequency variability in supra-long tree-ring chronologies from distant peatland sites in Ireland, Germany and the Netherlands, indicating a large-scale climatic driver. Also, long-distance cross-dating between tree-ring chronologies developed from subfossil peatland trees showed that tree growth must be influenced by large-scale climate regimes [11,69]. 


\subsection{Peatland Management}

Understanding mechanisms of hydrological responses to past climate is important for the present and future management of peatlands, especially since peatlands play an essential role in the global carbon budget [70]. Nevertheless, conditions and time scales are still discussed [1,71] for drained forested peatlands to act whether as a carbon source or sink [72-75] and to have a climate-warming or cooling impact. Hydrological variability significantly affects peatland carbon dynamics $[3,4,76]$ and climatic influences on long-term fluctuations of GWL, especially under climate change, necessarily must be considered.

Restoration of disturbed ecosystems is one of the available options for the management of peatlands. The aim of peatland restoration is to achieve a pre-drainage state and provide ecosystem services, e.g., by maintaining biodiversity and decreasing greenhouse gas emissions [4]. Reconstruction of past tree cover development, forest stand dynamics and the disturbance regime driven by climatic and hydrological variability, is also important for the planning of restoration activities and when assessing the outcomes. Tree cover reconstructions in peatlands may be invaluable for the estimation of the pre-drainage state and distinguishing between natural and man-made disturbances.

In the case of peatlands drained for forestry, mostly it is reasonable to continue forest management. Artificial drainage affects tree growth dynamics by changing site conditions, in general resulting in improved tree diameter and height increment [1]. Our results show that despite the altered hydrological regime in drained sites, the relationship between tree growth and hydroclimatic indices (which presumably reflect GWL fluctuations) is similar to undrained sites. Clearly, growth dynamics of peatland trees are driven by more than ditching, including factors unrelated to human activities such as climate. However, climate change affecting temperature-controlled evaporation and regional precipitation patterns can be human-induced [77]. Hence, long-term trends in hydroclimatic variability should be considered when predicting the growth and yield of drained peatland forest stands, planning silvicultural treatments and estimating their effects. Past and current trends in GWL are important, for example in the case of ditch network maintenance, since that directly influences the necessity and outcomes of the treatment [78].

The selection of drained sites suitable for climate change mitigation and forest management should consider productivity, however, in terms of carbon balance, variation between different peatland sites is rather high. Carbon balance depends on current and future climatic conditions and hydrological trends as well as on site type and fertility, pre-drainage state and forest management practices [72].

\section{Conclusions}

Tree-ring data of Scots pine sampled at peatland sites in 14 study areas in Estonia, Belarus, and Sweden were examined for similarities in growth trends and possible links to regional climate dynamics. The applied radial growth averaging method proved to be a valuable tool not only to detect growth release events, but also to compare tree growth dynamics between different sites. The developed tree-ring chronologies show common multi-annual to multi-decadal growth trends despite the differences in peatland site characteristics and management history. Synchronous growth releases were detected during the 20th century in the 1910s, 1930s, and around 1970 and 1990. The best agreements were observed among the trees in study areas within Estonia and when comparing sites between Estonia and Belarus. Common periods associated with changes in the growth dynamics of peatland trees could also be detected between Sweden and Estonia.

Growth releases and trends detected in single tree-ring chronologies may be driven by local factors such as the ones related to peatland management. However, common variations detected at multiple sites indicated that trees in different regions have responded to similar forcing mechanisms; synchronous growth trends were therefore linked to regional climate dynamics. The relationship between \%GC data and trends in scPDSI illustrates that detected growth releases were possibly associated with hydrological changes in the peatlands. Non-climatically induced changes in hydrology (artificial drainage) also affected tree growth, but growth releases were still found to be synchronous 
both in drained and undrained sites. Growth release events were detected several years prior to ditching, therefore changes in growth dynamics were initially not associated with drainage but induced climatically. Still, during the post-treatment period, tree growth on drained sites was determined also by an artificially lowered GWL.

Exploring links between regional climatic variability and processes that involve hydrology and vegetation responses is of great importance in decision-making and planning of sustainable (also climatically) land use and management, especially in the case of such sensitive and dynamic ecosystems as peatlands, which are key players in the global carbon cycle.

Supplementary Materials: The following are available online at http:/www.mdpi.com/1999-4907/10/12/1097/s1, Figure S1: Ring-width data of single trees (gray) and mean growth change (\%GC) series calculated using raw ring-width data (black line) and ring-width indices produced after applying different detrending methods; negative exponential (blue), autoregressive (green) and smoothing spline (wavelengths of 100, 30 and 10 years-red, orange and brown lines accordingly) models. The share of trees (filtered values, only greater than $20 \%$ are present) with detected growth release events are shown for each method on the bottom part of the graph. The graphs are for study areas 5 and 6 (southwest Belarus and northeast Estonia), Figure S2: Slope coefficients of linear models used for detrending after switching from a negative exponential model (unable to fit the model to the data) to linear in the case of $24 \%$ of trees in the dataset. Detrending procedure using negative exponential method was successful in case of $26 \%$ of trees; standardization by mean was performed for the rest $50 \%$ of sampled trees.

Author Contributions: Conceptualization, A.P., A.K., T.K., S.M. and M.H.; methodology, A.P., A.K., T.K., S.M. and M.H.; formal analysis, A.P.; investigation, A.P., S.T., M.Y., J.E. and A.L.; data curation, A.P., S.T., M.Y. and J.E.; writing—original draft preparation, A.P.; writing—review and editing, A.P., M.H., J.E., S.T., A.J., M.Y., A.K., S.M. and A.L.; visualization, A.P.

Funding: This research was funded by Estonian Ministry of Education and Research (Institutional Research Funding IUT21-4) and Swedish Research Council (2016-04726). The APC was funded by the Chair of Forest Management Planning and Wood Processing Technologies, Estonian University of Life Sciences.

Acknowledgments: This work was supported by Estonian State Forest Management Centre (RMK). We would like to acknowledge Anton Hansson for Store Mosse tree-ring data and Argo Strantsov for the help with Kanajalasoo and Ongassaare data. We are grateful to John A. Stanturf for discussion and language correction and to two anonymous reviewers, whose comments helped to improve this manuscript considerably.

Conflicts of Interest: The authors declare no conflict of interest. The funders had no role in the design of the study; in the collection, analyses, or interpretation of data; in the writing of the manuscript, or in the decision to publish the results.

\section{References}

1. Päivänen, J.; Hånell, B. Peatland Ecology and Forestry: A Sound Approach; University of Helsinki: Helsinki, Finland, 2012; ISBN 9789521045318.

2. Edvardsson, J.; Rimkus, E.; Corona, C.; Šimanauskienè, R.; Kažys, J.; Stoffel, M. Exploring the impact of regional climate and local hydrology on Pinus sylvestris L. growth variability-A comparison between pine populations growing on peat soils and mineral soils in Lithuania. Plant Soil 2015, 392, 345-356. [CrossRef]

3. Waddington, J.M.; Morris, P.J.; Kettridge, N.; Granath, G.; Thompson, D.K.; Moore, P.A. Hydrological feedbacks in northern peatlands. Ecohydrology 2015, 8, 113-127. [CrossRef]

4. Laine, A.M.; Mehtätalo, L.; Tolvanen, A.; Frolking, S.; Tuittila, E.S. Impacts of drainage, restoration and warming on boreal wetland greenhouse gas fluxes. Sci. Total Environ. 2019, 647, 169-181. [CrossRef] [PubMed]

5. Paavilainen, E.; Päivänen, J. Peatland Forestry; Springer: Berlin/Heidelberg, Germany, 1995; ISBN 978-3-642-08198-9.

6. Raudsaar, M.; Sims, A.; Timmusk, T.; Pärt, E.; Nikopensius, M. Forest Resources. In Yearbook Forest 2017; Raudsaar, M., Siimon, K.-L., Valgepea, M., Eds.; Keskkonnaagentuur: Tallinn, Estonia, 2018; pp. 17-86.

7. Macdonald, S.E.; Yin, F. Factors influencing size inequality in peatland black spruce and tamarack: Evidence from post-drainage release growth. J. Ecol. 1999, 87, 404-412. [CrossRef]

8. Freléchoux, F.; Buttler, A.; Schweingruber, F.H.; Gobat, J.-M. Stand structure, invasion, and growth dynamics of bog pine (Pinus uncinata var. rotundata) in relation to peat cutting and drainage in the Jura Mountains, Switzerland. Can. J. For. Res. 2000, 30, 1114-1126. [CrossRef] 
9. Hökkä, H.; Ojansuu, R. Height development of Scots pine on peatlands: Describing change in site productivity with a site index model. Can. J. For. Res. 2004, 34, 1081-1092. [CrossRef]

10. Linderholm, H.W.; Leine, M. An assessment of twentieth century tree-cover changes on a southern Swedish peatland combining dendrochronoloy and aerial photograph analysis. Wetlands 2004, 24, 357-363. [CrossRef]

11. Edvardsson, J.; Stoffel, M.; Corona, C.; Bragazza, L.; Leuschner, H.H.; Charman, D.J.; Helama, S. Subfossil peatland trees as proxies for Holocene palaeohydrology and palaeoclimate. Earth Sci. Rev. 2016, 163, 118-140. [CrossRef]

12. Dang, Q.L.; Lieffers, V.J. Assessment of patterns of response of tree ring growth of black spruce following peatland drainage. Can. J. For. Res. 1989, 19, 924-929. [CrossRef]

13. Sikström, U.; Hökkä, H. Interactions between soil water conditions and forest stands in boreal forests with implications for ditch network maintenance. Silva Fenn. 2016, 50. [CrossRef]

14. Läänelaid, A.; Eckstein, D. Norway spruce in Estonia reflects the early summer weather in its tree-ring widths. Balt. For. 2012, 18, 194-204.

15. Sohar, K.; Läänelaid, A.; Eckstein, D.; Helama, S.; Jaagus, J. Dendroclimatic signals of pedunculate oak (Quercus robur L.) in Estonia. Eur. J. For. Res. 2014, 133, 535-549. [CrossRef]

16. Hordo, M.; Kängsepp, V.; Kannimäe, T.; Kask, P. Annual growth trends and response to weather of larch trees at Järvselja Training and Experimental Forest Center stands (Estonia). For. Stud. 2015, 63, 111-129. [CrossRef]

17. Metslaid, S.; Stanturf, J.A.; Hordo, M.; Korjus, H.; Laarmann, D.; Kiviste, A. Growth responses of Scots pine to climatic factors on reclaimed oil shale mined land. Environ. Sci. Pollut. Res. 2016, 23, 13637-13652. [CrossRef] [PubMed]

18. Metslaid, S.; Hordo, M.; Korjus, H.; Kiviste, A.; Kangur, A. Spatio-temporal variability in Scots pine radial growth responses to annual climate fluctuations in hemiboreal forests of Estonia. Agric. For. Meteorol. 2018, 252, 283-295. [CrossRef]

19. Linderholm, H. Climatic influence on Scots pine growth on dry and wet soils in the central Scandinavian mountains, interpreted from tree-ring width. Silva Fenn. 2001, 35, 415-424. [CrossRef]

20. Vitas, A. Dendroclimatological research of Scots pine (Pinus sylvestris L.) in the Baltic coastal zone of Lithuania. Balt. For. 2004, 10, 65-71.

21. Hordo, M.; Henttonen, H.; Mäkinen, H.; Helama, S.; Kiviste, A. Annual growth variation of Scots pine in Estonia and Finland. Balt. For. 2011, 17, 35-49.

22. Jansons, Ā.; Matisons, R.; Šēnhofa, S.; Katrevičs, J.; Jansons, J. High-frequency variation of tree-ring width of some native and alien tree species in Latvia during the period 1965-2009. Dendrochronologia 2016, 40, 151-158. [CrossRef]

23. Cook, E.R. A Time Series Analysis Approach to Tree Ring Standardization. Ph.D. Thesis, The University of Arizona, Tucson, AZ, USA, 1985.

24. Peters, R.L.; Groenendijk, P.; Vlam, M.; Zuidema, P.A. Detecting long-term growth trends using tree rings: A critical evaluation of methods. Glob. Chang. Biol. 2015, 21, 2040-2054. [CrossRef]

25. Edvardsson, J.; Hansson, A. Multiannual hydrological responses in Scots pine radial growth within raised bogs in southern Sweden. Silva Fenn. 2015, 49. [CrossRef]

26. Charman, D.J.; Brown, A.D.; Hendon, D.; Karofeld, E. Testing the relationship between Holocene peatland palaeoclimate reconstructions and instrumental data at two European sites. Quat. Sci. Rev. 2004, 23, 137-143. [CrossRef]

27. Blanchet, G.; Guillet, S.; Calliari, B.; Corona, C.; Edvardsson, J.; Stoffel, M.; Bragazza, L. Impacts of regional climatic fluctuations on radial growth of Siberian and Scots pine at Mukhrino mire (central-western Siberia). Sci. Total Environ. 2017, 574, 1209-1216. [CrossRef] [PubMed]

28. Valgma, Ü. Impact of precipitation on the water table level of different ombrotrophic raised bog complexes, central Estonia. Suo 1998, 49, 13-21.

29. Yermokhin, M. The tree-ring chronology of Scots pine (Pinus sylvestris L.) from the Nesvizh castle XVI-XIX cc. in central Belarus. Dendrochronologia 2012, 30, 69-72. [CrossRef]

30. Yermokhin, M.; Mychko, V.; Knysh, N.; Uhlyanets, S.; Barsukova, T.; Dudkina, L.; Lukin, V. Transformation of pine bog forests in Belovezhskaya Pushcha-Drainage or climate change? In Proceedings of the EuroDendro 2017 Conference, Tartu, Estonia, 6-10 September 2017; p. 28. 
31. Potapov, A. Effect of construction of drainage system and ditch network maintenance on radial increment of trees. Master's Thesis, Estonian University of Life Sciences, Tartu, Estonia, 2016.

32. Toomik, S.; Sohar, K.; Läänelaid, A.; Jaagus, J. Climate and hydrology relations of pine (Pinus sylvestris L.) growing in some drained Central Estonian mires. In Proceedings of the EuroDendro 2017 Conference, Tartu, Estonia, 6-10 September 2017; p. 117.

33. Padari, A.; Kiviste, K. Modelling of postdrained forest growth. For. Stud. 2005, 43, 58-83.

34. Préfontaine, G.; Jutras, S. Variation in stand density, black spruce individual growth and plant community following 20 years of drainage in post-harvest boreal peatlands. For. Ecol. Manage. 2017, 400, 321-331. [CrossRef]

35. Cook, E.R.; Kairiukstis, L.A. Methods of Dendrochronology; Springer: Dordrecht, The Netherlands, 1990; ISBN 978-90-481-4060-2.

36. Holmes, R. Computer-assisted quality control in tree-ring dating and measurement. Tree-Ring Bull. 1983, 43, 69-75.

37. Nowacki, G.J.; Abrams, M.D. Radial-growth averaging criteria for reconstructing disturbance histories from presettlement-origin oaks. Ecol. Monogr. 1997, 67, 225-249. [CrossRef]

38. Abrams, M.D.; Copenheaver, C.A.; Terazawa, K.; Umeki, K.; Takiya, M.; Akashi, N. A 370-year dendroecological history of an old-growth Abies-Acer-Quercus forest in Hokkaido, northern Japan. Can. J. For. Res. 1999, 29, 1891-1899. [CrossRef]

39. Lorimer, C.G.; Frelich, L.E. A methodology for estimating canopy disturbance frequency and intensity in dense temperate forests. Can. J. For. Res. 1989, 19, 651-663. [CrossRef]

40. Rentch, J.S.; Desta, F.; Miller, G.W. Climate, canopy disturbance, and radial growth averaging in a second-growth mixed-oak forest in West Virginia, U.S.A. Can. J. For. Res. 2002, 32, 915-927. [CrossRef]

41. Rubino, D.L.; McCarthy, B.C. Comparative analysis of dendroecological methods used to assess disturbance events. Dendrochronologia 2004, 21, 97-115. [CrossRef]

42. Altman, J.; Fibich, P.; Dolezal, J.; Aakala, T. TRADER: A package for Tree Ring Analysis of Disturbance Events in R. Dendrochronologia 2014, 32, 107-112. [CrossRef]

43. Bunn, A.G. A dendrochronology program library in R (dplR). Dendrochronologia 2008, 26, 115-124. [CrossRef]

44. R Core Team. R: A Language and Environment for Statistical Computing; R Foundation for Statistical Computing: Vienna, Austria, 2016.

45. Palmer, W.C. Meteorological Drought; Research Paper 45; U.S. Department of Commerce, Weather Bureau: Washington, DC, USA, 1965; p. 58.

46. Van der Schrier, G.; Barichivich, J.; Briffa, K.R.; Jones, P.D. A scPDSI-based global data set of dry and wet spells for 1901-2009. J. Geophys. Res. Atmos. 2013, 118, 4025-4048. [CrossRef]

47. Osborn, T.; Barichivich, J.; Harris, I.; Van Der Schrier, G.; Jones, P. Monitoring global drought using the self-calibrating Palmer Drought Severity Index. In State of the Climate in 2015. Bull. Am. Meteorol. Soc. 2016, 97, S32-S36.

48. Trouet, V.; van Oldenborgh, G.J. KNMI Climate Explorer: A web-based research tool for high-resolution paleoclimatology. Tree Ring Res. 2013, 69, 3-13. [CrossRef]

49. Wells, N.; Goddard, S.; Hayes, M.J. A Self-Calibrating Palmer Drought Severity Index. J. Clim. 2004, 17, 2335-2351. [CrossRef]

50. Sarkkola, S.; Hökkä, H.; Penttilä, T. Natural development of stand structure in peatland Scots pine following drainage: Results based on long-term monitoring of permanent sample plots. Silva Fenn. 2004, 38, 405-412. [CrossRef]

51. Edvardsson, J.; Šimanauskien, R.; Taminskas, J.; Baužien, I.; Stoffel, M. Increased tree establishment in Lithuanian peat bogs-Insights from field and remotely sensed approaches. Sci. Total Environ. 2015, 505, 113-120. [CrossRef] [PubMed]

52. Dauškane, I. Influence of Climatic Factors on the Radial Growth of Scots Pine Pinus sylvestris L. on Mires in Latvia. Ph.D. Thesis, University of Latvia, Riga, Latvia, 2011.

53. Dauškane, I.; Brūmelis, G.; Elferts, D. Effect of climate on extreme radial growth of Scots pine growing on bogs in Latvia. Est. J. Ecol. 2011, 60, 236. [CrossRef]

54. Čugunovs, M.; Nikodemus, O.; Dauškane, I.; Brūmelis, G. The colonization history of Scots pine (Pinus sylvestris) in pristine and drained raised bogs in Latvia. Environ. Exp. Biol. 2016, 14, 97-106. [CrossRef] 
55. Taminskas, J.; Edvardsson, J.; Linkevičienè, R.; Stoffel, M.; Corona, C.; Tamkevičiūtè, M. Combining multiple proxies to investigate water table fluctuations in wetlands: A case study from the Rèkyva wetland complex, Lithuania. Palaeogeogr. Palaeoclimatol. Palaeoecol. 2019, 514, 453-463. [CrossRef]

56. Smiljanić, M.; Seo, J.-W.; Läänelaid, A.; van der Maaten-Theunissen, M.; Stajić, B.; Wilmking, M. Peatland pines as a proxy for water table fluctuations: Disentangling tree growth, hydrology and possible human influence. Sci. Total Environ. 2014, 500-501, 52-63. [CrossRef]

57. Edvardsson, J.; Adolphi, F.; Linderholm, H.W.; Corona, C.; Muscheler, R.; Stoffel, M. Periodicities in mid- to late-Holocene peatland hydrology identified from Swedish and Lithuanian tree-ring data. Quat. Sci. Rev. 2016, 137, 200-208. [CrossRef]

58. Payandeh, B. Analyses of a forest drainage experiment in Northern Ontario. I: Growth analysis. Can. J. For. Res. 1973, 3, 387-398. [CrossRef]

59. Jaani, A. Hydrology and water balance of Lake Peipsi. Hydrobiologia 1996, 338, 11-23. [CrossRef]

60. Zhao, H.; Gao, G.; An, W.; Zou, X.; Li, H.; Hou, M. Timescale differences between SC-PDSI and SPEI for drought monitoring in China. Phys. Chem. Earth Parts A B C 2017, 102, 48-58. [CrossRef]

61. Dudley, R.W.; Hodgkins, G.A.; Nielsen, M.G.; Qi, S.L. Estimating historical groundwater levels based on relations with hydrologic and meteorological variables in the U.S. glacial aquifer system. J. Hydrol. 2018, 562, 530-543. [CrossRef]

62. Guttman, N.B. Comparing the Palmer Drought Index and the Standardized Precipitation Index. J. Am. Water Resour. Assoc. 1998, 34, 113-121. [CrossRef]

63. Vicente-Serrano, S.M.; Beguería, S.; López-Moreno, J.I. Comment on "Characteristics and trends in various forms of the Palmer Drought Severity Index (PDSI) during 1900-2008” by Aiguo Dai. J. Geophys. Res. 2011, 116, D19112. [CrossRef]

64. Girardin, M.P.; Ali, A.; Carcaillet, C.; Mudelsee, M.; Drobyshev, I.; Hély, C.; Bergeron, Y. Heterogeneous response of circumboreal wildfire risk to climate change since the early 1900s. Glob. Chang. Biol. 2009, 15, 2751-2769. [CrossRef]

65. McKee, T.B.; Doesken, N.J.; Kleist, J. The relationship of drought frequency and duration to time scales. In Proceedings of the 8th Conference on Applied Climatology, Anaheim, CA, USA, 17-22 January 1993; pp. 179-183.

66. Leelaruban, N.; Padmanabhan, G.; Oduor, P. Examining the relationship between drought indices and groundwater levels. Water 2017, 9, 82. [CrossRef]

67. Vicente-Serrano, S.M.; Beguería, S.; López-Moreno, J.I. A multiscalar drought index sensitive to global warming: The Standardized Precipitation Evapotranspiration Index. J. Clim. 2010, 23, 1696-1718. [CrossRef]

68. Edvardsson, J.; Baužienè, I.; Lamentowicz, M.; Šimanauskienè, R.; Tamkevičiūtè, M.; Taminskas, J.; Linkevičienè, R.; Skuratovič, Ž.; Corona, C.; Stoffel, M. A multi-proxy reconstruction of moisture dynamics in a peatland ecosystem: A case study from Čepkeliai, Lithuania. Ecol. Indic. 2019, 106, 105484. [CrossRef]

69. Leuschner, H.H.; Sass-Klaassen, U.; Jansma, E.; Baillie, M.G.L.; Spurk, M. Subfossil European bog oaks: Population dynamics and long-term growth depressions as indicators of changes in the Holocene hydro-regime and climate. Holocene 2002, 12, 695-706. [CrossRef]

70. Yu, Z.C. Northern peatland carbon stocks and dynamics: A review. Biogeosciences 2012, 9, 4071-4085. [CrossRef]

71. Hommeltenberg, J.; Schmid, H.P.; Drösler, M.; Werle, P. Can a bog drained for forestry be a stronger carbon sink than a natural bog forest? Biogeosciences 2014, 11, 3477-3493. [CrossRef]

72. Minkkinen, K.; Laine, J.; Penttilä, T. Greenhouse gas emissions from forestry drained peatlands and contributing environmental factors. In Greenhouse Impacts of the Use of Peat and Peatlands in Finland; Report 11a/2007; Sarkkola, S., Ed.; Ministry of Agriculture and Forestry: Helsinki, Finland, 2008; pp. 22-26. ISBN 9789524533942.

73. Maljanen, M.; Sigurdsson, B.D.; Guömundsson, J.; Öskarsson, H.; Huttunen, J.T.; Martikainen, P.J. Greenhouse gas balances of managed peatlands in the Nordic countries-Present knowledge and gaps. Biogeosciences 2010, 7, 2711-2738. [CrossRef]

74. Lohila, A.; Minkkinen, K.; Aurela, M.; Tuovinen, J.P.; Penttilä, T.; Ojanen, P.; Laurila, T. Greenhouse gas flux measurements in a forestry-drained peatland indicate a large carbon sink. Biogeosciences 2011, 8, 3203-3218. [CrossRef] 
75. Ojanen, P.; Minkkinen, K.; Penttilä, T. The current greenhouse gas impact of forestry-drained boreal peatlands. For. Ecol. Manage. 2013, 289, 201-208. [CrossRef]

76. Strack, M.; Waddington, J.M.; Turetsky, M.; Roulet, N.T.; Byrne, K.A. Northern peatlands, greenhouse gas exchange and climate change. In Peatlands and Climate Change; Strack, M., Ed.; International Peat Society: Jyväskylä, Finland, 2008; pp. 44-69. ISBN 978-952-99401-1-0.

77. Sarojini, B.B.; Stott, P.A.; Black, E. Detection and attribution of human influence on regional precipitation. Nat. Clim. Chang. 2016, 6, 669-675. [CrossRef]

78. Sarkkola, S.; Hökkä, H.; Ahti, E.; Koivusalo, H.; Nieminen, M. Depth of water table prior to ditch network maintenance is a key factor for tree growth response. Scand. J. For. Res. 2012, 27, 649-658. [CrossRef]

C 2019 by the authors. Licensee MDPI, Basel, Switzerland. This article is an open access article distributed under the terms and conditions of the Creative Commons Attribution (CC BY) license (http://creativecommons.org/licenses/by/4.0/). 